\title{
Evaluasi Program Gerakan Literasi Sekolah (Gelis) Di Sekolah Dasar
}

\author{
Ivanka Restu Widy Trianggoro ${ }^{1 *}$, Henny Dewi Koeswanti ${ }^{2}$ (iD \\ 1,2 Pendidikan Guru Sekolah Dasar, Universitas Kristen Satya Wacana, Kota Salatiga, Negara Indonesia \\ *Corresponding author: ivankawidy212@gmail.com
}

\begin{abstract}
Abstrak
Rendahnya minat baca peserta didik di Indonesia merupakan permasalahan yang mengakibatkan menurunnya tingkat pemahaman peserta didik dalam proses pembelajaran. Penelitian ini bertujuan untuk menganalisis pelaksanaan evaluasi program gerakan literasi sekolah dalam upaya meningkatkan pemahaman sekaligus minat baca peserta didik. Model yang digunakan dalam penelitian adalah model Goal Free Evaluation sehingga tidak terfokus pada tujuan tertentu pada suatu program yang dievaluasi. Metode pengumpulan data yang digunakan yaitu wawancara, observasi, dan studi dokumen. Metode analisis data yang digunakan adalah analisis data deskriptif kualitatif yang meliputi tiga tahapan yaitu reduksi data, penyajian data, dan kesimpulan. Berdasarkan hasil penelitian menunjukkan bahwa pelaksanaan program gerakan literasi sekolah di SD masih belum menyeluruh dalam pelaksanaannya namun cukup memberikan dampak positif bagi beberapa kelas yang telah melaksanakan program gerakan literasi sekolah. Maka, evaluasi program gerakan literasi sekolah telah dilaksanakan cukup baik. Sehingga dengan adanya penelitian ini, dapat dijadikan acuan dalam menambah pengetahuan tentang evaluasi program gerakan literasi sekolah.
\end{abstract}

Kata kunci: Evaluasi Program, Gerakan Literasi Sekolah

\section{Abstract}

The low reading interest of students in Indonesia is a problem that results in a decrease in the level of understanding of students in the learning process. This study aims to analyze the implementation of the evaluation of the school literacy movement program in an effort to improve students' reading comprehension as well as interest in reading. The model used in this study is the Goal Free Evaluation model so that it is not focused on a particular goal in a program being evaluated. Data collection methods used are interviews, observations, and document studies. The data analysis method used is descriptive qualitative data analysis which includes three stages, namely data reduction, data presentation, and conclusions. Based on the results of the study, it is shown that the implementation of the school literacy movement program in elementary schools is still not comprehensive in its implementation but is sufficient to have a positive impact on several classes that have implemented the school literacy movement program. Thus, the evaluation of the school literacy movement program has been carried out quite well. So with this research, it can be used as a reference in increasing knowledge about evaluating the school literacy movement program.

Keywords: Program Evaluation, School Literacy Movement

\section{INTRODUCTION}

Kurikulum yang saat ini berlaku di Indonesia adalah kurikulum 2013 dimana dalam kurikulum 2013 ada 3 aspek yang harus dikembangkan kepada peserta didik, yaitu aspek pengetahuan, aspek sikap dan aspek keterampilan (Novika Auliyana et al., 2018; Persada et al., 2020). Salah satu upaya yang dilakukan pemerintah untuk mencapai tujuan pembelajaran dalam K13 adalah dengan membuat Gerakan Literasi Sekolah (GLS) (Ramandanu, 2019; Rohman, 2017). Program ini dilaksanakan untuk menumbuhkan minat baca peserta didik dan dapat meningkatkan keterampilan membaca agar pengetahuan dapat dikuasai secara lebih baik sehingga literasi itu sangat penting untuk diterapkan dalam pembelajaran (Ramandanu, 2019; Salma \& Mudzanatun, 2019; Wanelly, 2019). Hal tersebut karena literasi bukanlah sekedar keterampilan membaca dan menulis secara mekanis. Literasi meliputi tanggapan, pemahaman,

$\begin{array}{lll}\text { History: } & & \text { Publisher: Undiksha Press } \\ \text { Received } & : \text { September 14, } 2021 & \text { Licensed: This work is licensed under } \\ \text { Revised } & \text { : September 20, } 2021 & \text { a Creative Commons Attribution 3.0 License } \\ \text { Accepted } & \text { : October 25, 2021 } & \text { C. Dovember 25, } 2021\end{array}$


dan kegiatan kehidupan sehari-hari yang tersusun dan diaplikasikan melalui kegiatan pembelajaran yang berkelanjutan (Akbar, 2017; Purwati, 2017).

Namun kenyataannya, rendahnya minat baca peserta didik di Indonesia berdasarkan survei yang dilakukan oleh Kemendikbud tahun 2017. Menunjukkan bahwa peserta didik di Indonesia jarang sekali membaca buku yang rata - rata hanya 5 sampai 6 buku saja dalam satu tahun. Hal serupa juga diungkapkan oleh Programme for International Student Assesment (PISA) pada tahun 2018 peserta didik Indonesia menunjukkan kemampuan membacanya dengan memperoleh skor rata - rata 371 dari 500 (Mulyasa, 2021). Hal ini menunjukkan bahwa peserta didik Indonesia pandai dalam mencari informasi, mengevaluasi dan merefleksi informasi dari sebuah bacaan tetapi lemah dalam memahami informasi. Berdasarkan hasil wawancara dan observasi yang telah dilakukan pada kepala sekolah SDN Sidorejo Lor 05 yang menyampaikan bahwa proses pelaksanaan program gerakan literasi sekolah sebanyak 2 dari 6 kelas yang ada sudah melaksanakan kegiatan ini dengan baik selama pandemi covid-19 (Januari-April 2021). Selama pandemi berlangsung pembelajaran dilaksanakan secara daring melalu Whatsapp Group (WAG) pelaksanaan program gerakan literasi sekolah sendiri hanya berjalan pada dua kelas yaitu kelas IV dan kelas V karena terbatasnya sarana dan prasarana pada peserta didik sehingga banyak kelas yang tidak melaksanakan kegiatan tersebut. Jika hal tersebut dibiarkan terus menerus maka akan berdampak pada tingkat pemahaman peserta didik dan terganggunya proses pembelajaran.

Pelaksanaan program ini dilakukan untuk meningkatkan kemampuan memahami, mengembangkan, dan menerapkan apa yang telah dibaca oleh peserta didik (Purwo, 2019; Rohman, 2017). Banyak faktor yang mempengaruhi seseorang untuk mampu memahami sebuah informasi diantaranya adalah teknik atau strategi yang digunakan dalam membaca, lama kegiatan membaca, dan pengalaman seseorang dalam membaca pada kehidupan sehari hari (Novarina et al., 2019; Wanelly, 2019). Hal ini sesuai dengan tuntutan pembelajaran abad ke-21 pembelajaran multiliterasi merupakan pembelajaran yang dikembangkan atas keberagaman kemampuan siswa baik dari sisi kecerdasan, gaya belajar, maupun model belajarnya (Haryanti \& Saputra, 2019; Rohman, 2017). Salah satu faktor penghambat yaitu bahan bacaan yang tidak bervariatif dan tidak sesuai dengan minat peserta didik sangat berpengaruh terhadap keberhasilan program gerakan literasi sekolah (Tri Yunianika, 2019). Pelaksanaan evaluasi program perlu dilakukan untuk melihat bagaimana pelaksanaan program yang telah berjalan dan dapat digunakan sebagai tindak lanjut untuk kelangsungan program selanjutnya (Mas et al., 2019). Fungsi dari penelitian evaluasi sendiri adalah untuk mengetahui beberapa kemungkinan dari hal yang sudah direncanakan untuk dilaksanakan, dan sebarapa jauh tujuan yang dicapai (Mas et al., 2019).

Beberapa penelitian sebelumnya yang menyatakan bahwa manfaat yang dirasakan dengan adanya program literasi sekolah didapati peserta didik lebih semangat dalam belajar, tidak hanya terbatas pada membaca dan menulis saja, peserta didik mendapatkan jauh lebih baik ilmu pengetahuan dari bahan bacaan yang didapatkan (Magdalena et al., 2019). Pelaksanaan program ini mampu membantu peserta didik dalam meningkatkan prestasi belajar, peserta didik jadi lebih gemar membaca dan menulis, terciptanya suasana pembelajaran yang menyenangkan, ditunjang dengan adanya sarana dan prasana yang baik serta dibutuhkan kemampuan guru yang memadai (Mas et al., 2019). Hasil penelitian lain menemukan bahwa dengan adanya program Gerakan Literasi Sekolah ini peserta didik menjadi lebih terampil dalam mengembangkan gagasan, memahami, dan memecahkan masalah yang pada akhirnya peserta didik mampu menguasai kompetensi pembelajaran yang lebih baik (Fauziah et al., 2020). Oleh karena itu penelitian evaluasi ini dilaksanakan dengan tujuan untuk menganalisis pelaksanaan program Gerakan Literasi Sekolah dan memberikan tindak lanjut untuk kelangsungan program kedepannya 


\section{MATERIALS AND METHODS}

Jenis penelitian dengan metode deskriptif kualitatif yang menggunakan model Goal Free Evaluation. Model ini merupakan salah satu jenis evaluasi program yang menemukan tiga jenis pengaruh dari program, yaitu (1) Mengidentifikasi pengaruh negatif, (2) Mengidentifikasi pengaruh positif, (3) Mengidentifikasi pengaruh positif yang tidak termasuk dalam program (Absor et al., 2019). Model ini merupakan teknik yang dikembangkan dengan melaksanakan penilaian terhadap suatu program yang dilaksanakan memiliki manfaat sebagai langkah yang akan diputuskan untuk menentukan seberapa baik tujuan dari program tersebut dapat tercapai. Oleh karena itu secara diagramatik penelitian evaluasi program gerakan literasi digambarkan pada gambar 1 .

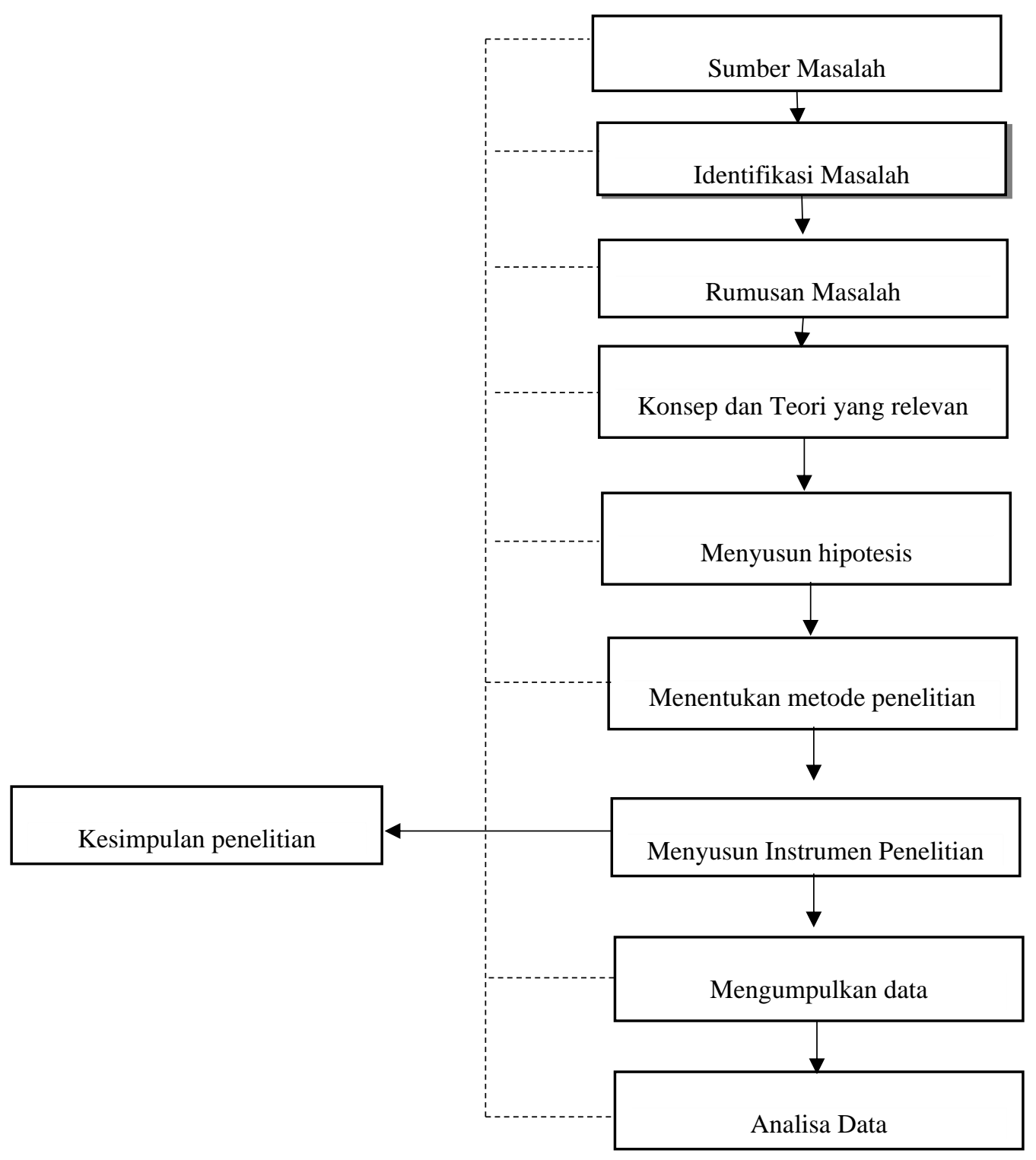

Gambar 1. Diagram Alur Desain penelitian

Penelitian ini menggunakan teknik pengumpulan data yaitu wawancara, observasi, studi dokumen dengan berupa instrumen lembar observasi dan pedoman wawancara. Setelah dilakukan pengumpulan data yang dibutuhkan untuk melihat pelaksanaan evaluasi program gerakan literasi sekolah ini maka selanjutnya data akan diolah untuk melihat tujuan dari program apakah sudah tersampaikan dengan baik, dan faktor apa saja yang mempengaruhi 
pelaksanaan evaluasi program. Dengan demikian setelah semua langkah sudah dilakukan maka akan didapatkan sebuah langkah tindak lanjut untuk pelaksanaan evaluasi program gerakan literasi sekolah di SDN Sidorejo Lor 05 . Teknik analisis data menggunakan uji kreadibilitas, uji confirmability, uji transferability.

\section{RESULTS AND DISCUSSION}

\section{Results}

Hasil dari penelitian menunjukkan bahwa visi, misi dan tujuan program sangat bermanfaat bagi peserta didik di sekolah. Didukung dengan kondisi sarana dan prasarana yang cukup memadai membuat kegiatan literasi ini dapat berjalan dengan baik. Dampak yang diberikan oleh pelaksanaan program gerakan literasi sekolah juga dirasakan cukup baik oleh peserta didik maupun guru di sekolah. Oleh karena itu keberhasilan dan hambatan yang terdapat pada proses literasi perlu dievaluasi untuk melihat dan dapat diambil keputusan sampai sejauh mana kegiatan itu telah dilaksanakan. Pelaksanaan proses evaluasi terhadap kelangsungan kegiatan program gerakan literasi sekolah dilakukan dari mulai kegiatan pembiasaan hingga kegiatan pembelajaran. Proses evaluasi ini dilakukan dengan harapan bahwa peserta didik dapat menumbuhkan budaya literasi sekaligus menerapkannya dalam kehidupan sehari - hari. Evaluasi gerakan literasi sekolah di SDN Sidorejo Lor 05 dilakukan dengan melihat kepada beberapa aspek yaitu latar belakang pelaksanaan program, kebijakan pelaksanaan program, strategi pelaksanaan program, faktor yang mempengaruhi pelaksanaan program, faktor yang mempengaruhi pelaksanaan program, dampak dari pelaksanaan program..

Berdasarkan hasil penelitian yang diperoleh program gerakan literasi sekolah yang ada di SDN Sidorejo Lor 05 sudah dilaksanakan sejak tahun 2017, pelaksanaannya didasari oleh Permendikbud No.23 Tahun 2015 tentang penumbuhan minat baca dengan kegiatan 15 menit membaca. Bagi sekolah sendiri ini merupakan upaya yang dilakukan agar peserta didik secara mandiri dan terbiasa mencari pengetahuan baru yang sesuai dengan minatnya dengan cara membaca. Dalam kegiatan literasi tersebut selain mendapatkan pengetahuan baru bagi peserta didik diharapkan peserta didik juga dapat meningkatkan prestasi belajaranya. Program ini diimplementasikan dengan menerapkan membaca selama 15 menit dan dibagi dalam tiga tahapan yaitu tahap pembiasaan, tahap pengembangan, tahap pembelajaran. Kegiatan membaca berlangsung dimana saja ketika dikelas peserta didik membaca menggunakan sudut baca kelas yang sudah tersedia disetiap masing - masing kelas, tidak lupa juga peserta didik diarahkan untuk membaca diperpustakaan untuk mendapatkan pengetahuan yang baru. Kegiatan membaca tersebut dilakukan setiap 15 menit sebelum kegiatan pembelajaran dimulai kemudian peserta didik diminta untuk menulis informasi apa yang telah didapatkan pada buku khusus yang telah disiapkan oleh sekolah, sehingga guru dapat mengetahui sekaligus menilai sampai sejauh pemahaman peserta didik dapat berkembang setiap setelah melakukan literasi di sekolah. Berikut adalah foto buku yang dimiliki dan kegiatan yang dilaksanankan setiap peserta didik dalam mengikuti proses kegiatan gerakan literasi sekolah.

Dalam prosesnya juga terdapat faktor pendukung yang mempengaruhi pelaksanaan program gerakan literasi sekolah di SDN Sidorejo Lor 05 yaitu meliputi lingkungan belajar yang mendukung untuk pelaksanaan program gerakan literasi sekolah dengan adanya sarana dan prasarana yang memadai seperti koleksi buku di sudut baca kelas maupun yang terdapat di perpustakaan sekolah. Dampak dari pelaksanaan evaluasi program gerakan literasi sekolah di SDN Sidorejo Lor 05 berdasarkan hasil penelitian dapat diketahui bahwa dari beberapa strategi yang diterapkan untuk menanamkan pembiasaan membaca pada peserta didik membawa dampak positif bagi setiap peserta didik. Peserta didik menjadi lebih tertarik untuk membaca, 
tingkat kemampuan pemahaman peserta didik juga lebih baik sehingga nilai hasil pembelajaran di kelas juga meningkat cukup signifikan.
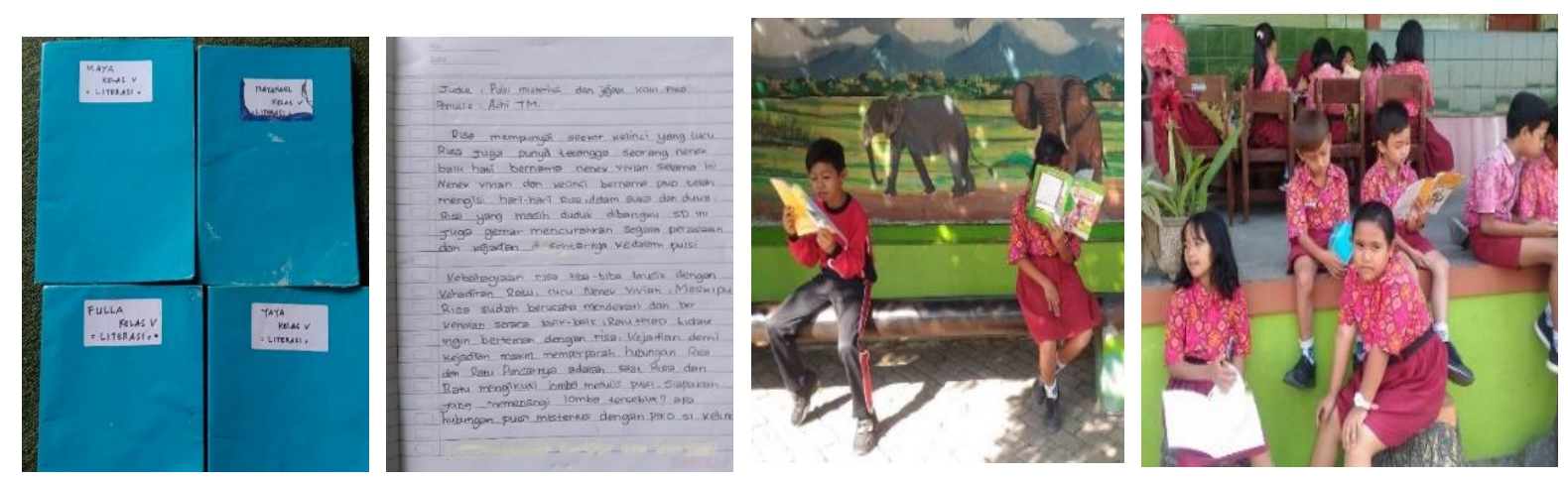

Gambar 2. Kegiatan Yang Dilaksanankan Setiap Peserta Didik Dalam Mengikuti Proses Kegiatan Gerakan Literasi Sekolah

\section{Discussion}

Berdasarkan hasil penelitian yang telah dijelaskan ditemukan bahwa evaluasi gerakan literasi sekolah sangat membantu bagi sekolah untuk mengetahui sejauh mana efektifitas program yang sudah dilaksanakan. Gerakan literasi sekolah yang sudah berjalan sejak tahun 2016 kurang lebih sekitar 5 tahun namun dalam pelaksanaannya banyak guru yang belum membaca buku panduan gerakan literasi sekolah yang diterbitkan oleh Kemendikbud. Beberapa guru beralasan bahwa tidak ada guru lain maupun pihak sekolah yang memberitahukan keberadaan buku panduan tersebut (Antoro et al., 2021). Hal ini menjadi salah satu faktor yang menghambat proses berjalannya program gerakan literasi sekolah di SDN Sidorejo Lor 05. Namun pihak sekolah sendiri sudah berupaya untuk terus memperbarui sarana dan prasarana yang ada sehingga tidak membuat peserta didik berkurang minatnya untuk membaca. Hal - hal seperti ini sangat diperlukan karena banyak buku - buku sekolah sudah tidak layak dan terlampau lama, sehingga diperlukan buku - buku yang lebih baru untuk meningkatkan minat baca peserta didik (Wahyuni et al., 2018; Widayoko \& Muhardjito, 2018).

Pelaksanaan program gerakan literasi sekolah ini dilaksanakan pada saat proses pembelajaran maupun diluar proses pembelajaran. Pelaksanaan program gerakan literasi ini berfokus pada kegiatan membaca, menulis, dan diskusi. Namun pelaksaanaan program gerakan literasi sekolah di SDN Sidorejo Lor 05 memiliki kelemahan salah satunya adalah guru kurang tanggap untuk memberikan penilaian atau melihat hasil yang didapatkan oleh peserta didik setelah membaca guru hanya terfokus pada kegiatan membaca yang dilakukan oleh peserta didiknya. Guru hendaknya lebih disiplin untuk melihat hasil sebagai tindak lanjut kepada peserta didik setelah membaca dan guru harus lebih kreatif dalam memilih topik atau melakukan variasi pada kegiatan membaca yang berbeda (Nurdiyanti \& Suryanto, 2010; Purwo, 2019). Kegiatan membaca merupakan salah satu faktor yang mendorong seseorang untuk memiliki maupun mengasah keterampilan berbahasanya. Membaca menjadi kegiatan yang harus dilakukan dan menjadi kebutuhan bagi peserta didik (Akbar, 2017; Rohman, 2017; Wanelly, 2019). Membaca adalah salah satu sarana untuk mendapatkan akses terhadap semua pengetahuan di dunia ini (Alam \& Lestari, 2020; Nopilda \& Kristiawan, 2018; Sari, 2020). Dalam membaca seseorang berarti sedang berusaha untuk menemukan informasi yang terdapat dalam bacaan dan menjadi bekal pengetahuan dalam kehidupan sehari - hari. Karena membaca sendiri adalah sebuah langkah dari kegiatan literasi maka literasi sendiri tidak dapat terlepas dari dunia pendidikan.

Faktor lingkungan di dalam maupun di luar sekolah juga sangat berpengaruh pada perkembangan kemampuan dan minat membaca peserta didik. Hal ini menjadi salah satu faktor 
pendukung atas kelangsungan program gerakan literasi sekolah di SDN Sidorejo Lor 05 karena memiliki lingkungan belajar yang nyaman sehingga peserta didik menjadi lebih bersemangat lagi dalam mengikuti proses berjalannya program ini. Selain itu perlunya menciptakan suasana literasi juga menjadi hal penting untuk mengampanyekan gerakan literasi salah satunya dengan membuat poster yang berisi ajakan untuk melakukan kegiatan positif. Literasi dilakukan untuk mengidentifikasi fakta serta menemukan dan mengkomunikasikan fakta untuk mengatasi aneka macam persoalan yang diharapakan setiap individu mendapatkan pembelajaran sepanjang hayat (Ismayani, 2013; Ramandanu, 2019). Oleh karena itu literasi erat kaitannya dengan peserta didik baik dalam lingkungan rumah, sekolah, maupun masyarakat. Dampak yang dirasakan setelah berjalannya program gerakan literasi sekolah di SDN Sidorejo Lor 05 juga cukup positif dapat dilihat dari meningkatnya hasil pembelajaran yang diperoleh peserta didik dan tingkat pemahaman peserta didik yang lebih baik. Namun dalam pelaksanaannya pihak sekolah hanya berfokus pada strategi yang sudah diberikan oleh Kemendikbud yaitu (1) Tahap Pembiasaan, (2) Tahap Pengembangan, dan (3) Pembelajaran belum ada strategi khusus yang diberikan oleh guru maupun pihak sekolah untuk mengembangkan program gerakan literasi sekolah ini. Adanya gerakan literasi sekolah membuat minat dan kemampuan membaca peserta didik meningkat sekaligus kecakapan peserta didik dalam berdiskusi setelah melakukan pembacaan terhadap jenis bacaan yang dipilihnya .

Evaluasi dilakukan saat proses pembelajaran berlangsung, tujuannya adalah untuk memberikan pantuan pada setiap perkembangan peserta didik dan memberikan umpan balik untuk peserta didik secara berkala (Magdalena et al., 2019; Septiary \& Sidabutar, 2020). Temuan ini diperkuat dengan penelitian sebelumnya yang menyatakan dengan dilaksanakannya evaluasi program gerakan literasi sekolah guru, kepala sekolah, dan peserta didik berhasil memahami tujuan umum dan tujuan khusus gerakan literasi sekolah (Mas et al., 2019). Hasil dari penelitian dan observasi yang telah dilakukan evaluasi program gerakan literasi ini layak untuk terus dilakukan. Salah satu faktor yang memengaruhi evaluasi ini adalah masih adanya kelemahan dari program yang dijalankan sehingga perlu dilakukan pengukuran untuk menngetahui sejauh mana keberhasilan pelaksanaan dari program gerakan literasi sekolah ini. Adanya sarana yang cukup memadai harus dapat dimaksimalkan sebaik mungkin salah satunya adalah perpustakaan sekolah.

\section{CONCLUSION}

Pelaksanaan program gerakan literasi di SDN Sidorejo Lor 05 mengalami peningkatan yang cukup signifikan dan sudah mengikuti arahan yang dikeluarkan oleh Kemendikbud. Sekolah sudah menyiapkan pelaksanaan program dengan baik terbukti dengan menyediakan sarana dan prasarana yang memadai seperti memperbarui buku di perpustakaan dan sudut baca kelas. Sekolah juga sudah menyediakan lingkungan yang nyaman sehingga tercipta suasana belajar yang menyenangkan bagi peserta didik. Dampak dari pelaksanaan program juga memberikan dampak positif terbukti dengan meningkatkan prestasi belajar dan tingkat pemahaman peserta didik. Masih terdapat kelemahan pada program gerakan literasi sekolah yang dilaksanakan oleh SDN Sidorejo Lor 05 karena guru belum memikirkan untuk serius mengukur hasil dari setelah peserta didik berliterasi dengan membaca kemudian menulis.

\section{REFERENCES}

Absor, N. F., Kurniawati, \& Umasih. (2019). Evaluasi Program Pembelajaran Sejarah Indonesia di SMKN 57 Jakarta. Jurnal Pendidikan Sejarah, 8(2), 170-194. https://doi.org/10.21009/jps.082.05.

Akbar, A. (2017). Membudayakan Literasi Dengan Peogram 6M Di Sekolah Dasar. Jurnal 
Pendidikan Sekolah Dasar, 3(1). https://doi.org/10.30870/jpsd.v3i1.1093.g2690.

Alam, S. K., \& Lestari, R. H. (2020). Pengembangan Kemampuan Bahasa Reseptif Anak Usia Dini dalam Memperkenalkan Bahasa Inggris melalui Flash Card. Jurnal Obsesi : Jurnal Pendidikan Anak Usia Dini, 4(1), 284. https://doi.org/10.31004/obsesi.v4i1.301. Antoro, B., Boeriswati, E., \& Leiliyanti, E. (2021). Pelaksanaan Gerakan Literasi Sekolah di Sekolah Menengah Pertama. Jurnal KIBASP (Kajian Bahasa, Sastra Dan Pengajaran), 5(1), 1-15. https://doi.org/10.31539/kibasp.v5i1.2474.

Fauziah, S. N., Faziah, S. N., Nupus, F. S., Ulfi, N., \& Sapitri, S. (2020). Evaluasi Minat Baca Siswa melalui Program Literasi Sekolah. NUSANTARA: Jurnal Ilmu Pengetahuan Sosial, 2(1), 108-116. https://doi.org/10.36088/nusantara.v2i1.641.

Haryanti, Y. D., \& Saputra, D. S. (2019). Instrumen Penilaian Berpikir Kreatif Pada Pendidikan Abad 21. Jurnal Cakrawala Pendas, 5(2). https://doi.org/10.31949/jcp.v5i2.1350.

Ismayani, M. R. (2013). Kreativitas dalam Pembelajaran Literasi Teks Sastra. Semantik, 2(2), 67-86.

Magdalena, I., Akbar, M., Situmorang, R., \& Rosnaningsih, A. (2019). Evaluasi Program Gerakan Literasi Sekolah di Sekolah Dasar Wilayah Kota dan Kabupaten Tanggerang. Pendas:Jurnal Pendidikan Dasar, 4(2), 230-248. https://doi.org/10.23969/jp.v4i2.1768.

Mas, S. R., Daud, N. K. P., \& Djafri, N. (2019). Evaluasi Pelaksanaan Program Gerakan Literasi Sekolah di Sekolah Dasar Negeri. Jurnal Manajemen Dan Supervisi Pendidikan, 4(1), 45-51. https://doi.org/10.17977/um025v4i12019p045.

Mulyasa. (2021). Menjadi Guru Penggerak Merdeka Belajar. PT Bumi Aksara.

Nopilda, L., \& Kristiawan, M. (2018). Gerakan literasi sekolah berbasis pembelajaran multiliterasi sebuah paradigma pendidikan abad ke-21. JMKSP (Jurnal Manajemen, Kepemimpinan, Dan Supervisi Pendidikan), 3(2), 216-231. https://doi.org/10.31851/jmksp.v3i2.1862.

Novarina, G. E., Santoso, A., \& Furaidah. (2019). Model Pelaksanaan Gerakan Literasi Sekolah di Sekolah Dasar. Jurnal Pendidikan: Teori, Penelitian Dan Pengembangan, 4(11), 1448-1456. https://doi.org/10.17977/jptpp.v4i11.12989.

Novika Auliyana, S., Akbar, S., \& Yuniastuti. (2018). Penerapan Pembelajaran Tematik Terpadu di Sekolah Dasar. Jurnal Pendidikan: Teori, Penelitian, Dan Pengembangan, 3(12), 1572-1582. https://doi.org/10.17977/jptpp.v3i12.11796.

Nurdiyanti, E., \& Suryanto, E. (2010). Pembelajaran Literasi Mata Pelajaran Bahasa Indonesia pada Siswa Kelas V Sekolah Dasar. Paedagogia, 13(2), 115-128. https://jurnal.fkip.uns.ac.id/index.php/paedagogia/article/view/153/104.

Persada, Y. I., Djatmika, E. T., \& Degeng, I. N. S. (2020). Pelaksanaan Pendekatan Scientific Dalam Pembelajaran Tematik. Jurnal Pendidikan: Teori, Penelitian, Dan Pengembangan, 5(1), 114-120. https://doi.org//10.17977/jptpp.v5i1.13151.

Purwati, S. (2017). Program Literasi Membaca 15 Menit Sebelum Pelajaran Dimulai Untuk Meningkatkan Hasil Belajar Membaca Dan Menghafal Surah Pendek. Jurnal Ilmu Pendidikan Sosial, Sains, Dan Humaniora, 3(4), 663-670.

Purwo, S. (2019). Peran Gerakan Literasi Sekolah Dalam Pembelajaran Kreatif Produktif di Sekolah Dasar. Journal of Chemical Information and Modeling, 53(9), 1689-1699. https://journal.stkippgritrenggalek.ac.id/index.php/kid/article/view/85/48.

Ramandanu, F. (2019). Gerakan Literasi Sekolah (GLS) Melalui Pemanfaatan Sudut Baca Kelas Sebagai Sarana Alternatif Penumbuhan Minat Baca Siswa. Jurnal Mimbar Ilmu, 24(1). https://doi.org/10.23887/mi.v24i1.17405.

Rohman, S. (2017). Membangun Budaya Membaca Pada Anak Melalui Program Gerakan Literasi Sekolah. Jurnal Pendidikan Dan Pembelajaran Dasar, 4(1), 156.

Salma, \& Mudzanatun. (2019). Analisis Gerakan Literasi Sekolah Terhadap Minat Baca Siswa 
Siswa Sekolah Dasar. Mimbar PGSD Undiksha, 7(2), 122-127. https://doi.org/http://dx.doi.org/10.23887/jjpgsd.v7i2.17555.

Sari, P. A. P. (2020). Hubungan Literasi Baca Tulis Dan Minat Membaca Dengan Hasil Belajar Bahasa Indonesia. Journal for Lesson and Learning Studies, 3(1), 141-152.

Septiary, D., \& Sidabutar, M. (2020). Pelaksanaan program gerakan literasi sekolah (GLS) di SD Muhammadiyah Sokonandi. Epistema, 1(1), 1-12. https://doi.org/10.21831/ep.v1i1.32054.

Tri Yunianika, I. (2019). Implementasi Gerakan Literasi Sekolah di Sekolah Dasar Dharma Karya Universitas Terbuka. Jurnal Ilmiah Sekolah Dasar, 4(3), 497-503. https://doi.org/10.23887/jisd.v3i4.

Wahyuni, P. D., Djatmika, E. T., \& As'ari, A. R. (2018). Pengaruh Full Day School dan Gerakan Literasi Sekolah terhadap Hasil Belajar dengan Mediasi Motivasi Belajar. Jurnal Pendidikan: Teori, Penelitian, Dan Pengembangan, 3(5), 679-684. https://doi.org/10.17977/jptpp.v3i5.11096.

Wanelly, W. (2019). Implementasi Kebijakan Gerakan Literasi Sekolah (GLS) Dalam Rangka Menumbuhkan Minat Baca Siswa Di Sekolah Dasar. Jurnal Basicedu, 2(3), 406 - 413. https://doi.org/10.31004/basicedu.v3i2.19.

Widayoko, A., \& Muhardjito, M. (2018). Analisis Program Implementasi Gerakan Literasi Sekolah (Gls) Dengan Pendekatan Goal-Based Evaluation. Jurnal Tatsqif, 16(1), 7892. https://doi.org/10.20414/jtq.v16i1.134. 